\title{
DIPARE UNTUK MENSUKSESKAN PEMBELAJARAN DARING PADA MASA PANDEMI COVID 19
}

\author{
SUHARNI \\ SDN Plosojenar Kec. Jakenan, Kab. Pati, Jawa Tengah \\ Email: suharni1967@gmail.com
}

\begin{abstract}
ABSTRAK
Latar belakang disusunnya karya ilmiah ini adalah adanya himbauan dari pemerintah terkait adanya pandemi COVID-19 maka untuk memutus mata rantai penyebaran COVID-19 pembelajaran dilakukan secara daring. Untuk mengatasi permasalahan-permasalahan yang muncul pada pelaksanaan pembelajaran daring dan untuk meningkatkan kualitas pembelajaran daring maka kepala sekolah SD Negeri Plosojenar menerapkan kebijakan DIPARE untuk mensukseskan pembelajaran daring pada masa pandemi COVID-19. Tujuan karya ilmiah ini adalah: 1) Memaparkan pelaksanaan DIPARE untuk mensukseskan pembelajaran daring, 2) Memaparkan hasil atau dampak dari pelaksanaan kegiatan DIPARE di SD Negeri Plosojenar, 3) Memaparkan tindak lanjut pengembangan kegiatan DIPARE untuk mensukseskan pembelajaran daring di SD Negeri Plosojenar Kecamatan Jakenan Kabupaten Pati. Pelaksanaan kegiatan DIPARE (diskusi, inovasi, partisipasi, akuntabel, reword, dan evaliasi) dilaksanakan dalam upaya menampung hambatan-hambatan yang terjadi dalam pembelajaran daring, serta melibatkan semua warga sekolah dalam mengatasi hambatan-hambatan yang muncul tersebut. Peran dari semua pihak diharapkan dapat mampu mengatasi hambatan-hambatan yang muncul sehingga kualitas pembelajaran daring dapat meningkat. Hasil dari pelaksanaan kegiatan DIPARE menunjukkan bahwa partisipasi dari semua warga sekolah sangat membantu dalam meningkatkan kualitas pembelajaran daring dan meningkatkan profesionalisme para pendidik. Dari hasil kegiatan tersebut guru sebagai pendidik mendapatkan pengalaman serta pengetahuan dalam menerapkan berbagai aplikasi yang dapat digunakan pembelajaran daring sehingga pembelajaran dapat berjalan dengan baik dan menyenangkan.
\end{abstract}

Kata Kunci: DIPARE, Pembelajaran Daring, Pandemi COVID-19

\section{ABSTRACT}

The background for the preparation of this scientific paper is an appeal from the government regarding the COVID-19 pandemic, so to break the chain of spread of COVID-19 learning is carried out online. To overcome the problems that arise in the implementation of online learning and to improve the quality of online learning, the principal of SD Negeri Plosojenar implements the DIPARE policy to make online learning successful during the COVID-19 pandemic. The objectives of this scientific paper are: 1) Describe the implementation of DIPARE for the success of online learning, 2) Describe the results or impacts of implementing DIPARE activities at SD Negeri Plosojenar, 3) Describe the follow-up to the development of DIPARE activities to make online learning successful at SD Negeri Plosojenar, Jakenan District Starch. The implementation of DIPARE activities (discussion, innovation, participation, accountability, reword, and evaluation) is carried out in an effort to accommodate the obstacles that occur in online learning, and involve all school members in overcoming the obstacles that arise. The role of all parties is expected to be able to overcome the obstacles that arise so that the quality of online learning can increase. The results of the implementation of DIPARE activities show that the participation of all school members is very helpful in improving the quality of online learning and increasing the professionalism of educators. From the results of these activities, teachers as educators gain experience and knowledge in implementing various applications that can be used for online learning so that learning can run well and is fun.

Keywords: DIPARE, Online Learning, COVID-19 Pandemic 


\section{PENDAHULUAN}

COVID-19 adalah penyakit menular yang disebabkan oleh jenis coronavirus yang baru ditemukan. Walaupun lebih banyak menyerang ke lansia, virus ini sebenarnya bisa juga menyerang siapa saja, mulai dari bayi, anak-anak, hingga orang dewasa. Virus corona ini bisa menyebabkan ganguan ringan pada sistem pernapasan, infeksi paru-paru yang berat, hingga kematian. COVID-19 ini merupakan penyakit menular yang sangat cepat menyebar, baik secara langsung maupun tidak langsung, dari satu orang ke orang lain di seluruh negeri di belahan dunia, termasuk Indonesia.Hal ini membuat pemerintah menerapkan kebijakan ketat untuk memutus rantai penyebaran COVID-19. Salah satu cara untuk memutus mata rantai penyebaran COVID-19 adalah dengan melakukan pembatasan interaksi masyarakat yang diterapkan dengan istilah physical distancing. Namun, kebijakan physical distancing tersebut dapat menghambat laju pertumbuhan dalam berbagai bidang kehidupan, baik bidang ekonomi, sosial dan tentu saja pendidikan.Keputusan pemerintah untuk meliburkan para peserta didik, memindahkan proses belajar mengajar di sekolah menjadi di rumah (sistem daring).

Penerapkan metode belajar dengan sistem daring (dalam jaringan) atau melalui system online merupakan sistem pembelajaran tanpa tatap muka secara langsung antara guru dan siswa tetapi dilakukan melalui online yang menggunakan jaringan internet. Hal ini sejalan dengan pendapat Zaky (dalam Yuliani, et al., 2020), sistem pembelajaran tidak menitikberatkan pada pertemuan tatap muka langsung antara pengajar dan peserta didik di dalam kelas, melainkan melalui proses digital yang dapat diakses di mana saja dan kapan saja.

Menurut Muhson (dalam Yuliani, et al., 2020) bahwa penggunaan Teknologi Informasi (TI) sebagai media pembelajaran sudah merupakan suatu tuntutan di era globalisasi dan informasi ini. Bentuk perkembangan teknologi informasi yang dapat dimanfaatkan sebagai media pembelajaran adalah e-learning yang tidak hanya dalam penyampaian materi pembelajaran akan tetapi dalam kemampuan berbagai kompetensi peserta didik juga.Dengan melalui e-learning peserta didik tidak hanya mendengarkan uraian materi dari pendidik, tetapi juga aktif mengamati, melakukan, mendemonstrasikan, dan sebagainya. Peserta didik lebih jauh termotifasi dalam proses pembelajaran karena materi bahan ajar dapat divirtualkan dalam berbagai format sehingga lebih menarik dan lebih dinamis.(Wiwin dalam Yuliani, et al., 2020). Hal ini sesuai dengan himbauan Menteri Pendidikan dan Kebudayaan Indonesia melalui Surat Edaran Nomor 4 Tahun 2020 tentang Pelaksanaan Kebijaksanaan Pendidikan dalam masa Darurat Penyebaran Corona Virus Disease ( COVID-19). Sistem pembelajaran dilaksanakan melalui perangkat personal computer (PC), Laptop atau handphone yang terhubung dengan koneksi jaringan internet. Guru dapat melakukan pembelajaran bersama diwaktu yang sama menggunakan grup di media sosial seperti WhatsApp, telegram, Aplikasi Zoom Cloud Meeting ataupun media lainnya. Dengan demikian, guru dapat memastikan siswa mengikuti pembelajaran dalam waktu yang bersamaan, meskipun di tempat yang berbeda.

Untuk itu setiap guru mau tidak mau dituntut untuk mengembangkan pembelajaran daring mulai dari penguasaan aplikasi-aplikasi yang mendukung pembelajaran maupun syang dapat diterapkan dalam pembelajaran. Inovasi-inovasi diperlukan oleh guru agar siswa tidak merasa bosan dalam pembelajaran. Sebagai langkah untuk memaksimalkan pembelajaran daring pada masa pandemi COVID-19 ini kepala sekolah dan guru selalu berupaya melakukan langkah-langkah dan membuat program agar pembelajaran berjalan dengan baik dan menghasilkan output yang baik juga. Hal itu dikarenakan banyak sekali kendala-kendala yang dihadapi dalam pembelajaran daring.

Pembelajaran daring tidak bisa lepas dari jaringan internet. Koneksi jaringan internet menjadi salah satu kendala yang dihadapi siswa yang tempat tinggalnya di pinggiran kota. Perlu disadari bahwa ketidaksiapan guru dan siswa terhadap pembelajaran daring juga menjadi masalah. Kegagapan pembelajaran daring memang nampak terlihat di hadapan kita, tidak satu atau dua sekolah saja melainkan menyeluruh di beberapa daerah di Indonesia.

Selain itu, sarana dan prasarana juga menjadi kendala. Penyebabnya adalah kesenjangan sosial yang terjadi di masyarakat. Di lapangan masih ditemukan ada beberapa siswa yang tidak 
memiliki handphone berbasis androit sehingga mengalami kendala dalam pembelajaran. Hal itu diperparah dengan pengetahuan dan kemampuan orang tua siswa yang belum terbiasa dengan penggunaan teknologi untuk mendukung pembelajaran daring, sehingga orang tua siswa tidak dapat mendampingi anaknya dalam pembelajaran daring.

Dengan kondisi tersebut menjadikan kepala SD Negeri Plosojenar Kec. Jakenan Kab. Pati selaku manajerial melakukan inovasi dan terobosan agar pembelajaran pada masa pandemi COVID-19 ini tetap berjalan baik. Kepala SD Negeri Plosojenar mendesain konsep pengembangan pembelajaran daring dengan menerapkan DIPARE (Diskusi, Inovasi, Partisipasi, Akuntabel, Reward (Penghargaan), dan Evaluasi) yang bermuara pada pencapai pembelajaran yang sesuai dengan visi dan misi sekolah di mana kegiatan tersebut melibatkan peserta didik, guru, orang tua siswa, komite sekolah, masyarakat, serta jajaran dinas pendidikan. Hasil dari langkah smart yang dilakukan oleh kepala sekolah dengan menerapkan DIPARE diharapkan mampu mewujudkan pembelajaran daring berkwalitas dan menyengkan sehingga terlahirlah pembelajaran yang menyenangkan bagi siswa SD Negeri Plosojenar.

Penerapan DIPARE diharapkan dapat mensukseskan pembelajaran daring pada masa PANDEMI-19 dan meningkatkan kwalitas pembelajaran dan output bagi peserta didik. Selain itu juga terjadi system yang sinergis antara sekolah dan orang tua siswa, komite sekolah, jajaran dinas pendidikan, dan masyarakat yang dapat meningkatkan prestasi siswa dan prestasi sekolah sehingga membanggakan bagi SD Negeri Plosojenar.

Berdasarkan latar belakang masalah tersebut, dapat dirumuskan permasalahan sebagai berikut: 1) Bagaimanakah penerapan DIPARE untuk mensukseskan pembelajaran daring di SD Negeri Plosojenar Kecamatan Jakenan Kabupaten Pati?, 2) Bagaimanakah hasil atau dampak dari pelaksanaan kegiatan DIPARE di SD Negeri Plosojenar Kecamatan Jakenan Kabupaten Pati?, 3) Bagaimanakah tindak lanjut pengembangan kegiatan DIPARE untuk mensukseskan pembelajaran daring di SD Negeri Plosojenar Kecamatan Jakenan Kabupaten Pati?.

Tujuan penulisan ini adalah: 1) memaparkan pelaksanaan DIPARE untuk mensukseskan pembelajaran daring di SD Negeri Plosojenar Kecamatan Jakenan Kabupaten Pati, 2) Memaparkan hasil atau dampak dari pelaksanaan kegiatan DIPARE di SD Negeri Plosojenar Kecamatan Jakenan Kabupaten Pati, 3) Memaparkan tindak lanjut pengembangan kegiatan DIPARE untuk mensukseskan pembelajaran daring di SD Negeri Plosojenar Kecamatan Jakenan Kabupaten Pati.

\section{METODE PENELITIAN}

Penelitian ini menggunakan pendekatan kualitatif dengan metode studi kasus karena penelitian ini bertujuan untuk menggali informasi dengan mempertahankan keutuhan subjek penelitian sebagai satu kesatuan yakni Best Practice Penyelenggaraan DIPARE (Diskusi, Inovasi, Partisipasi, Akuntabel, Reward, dan Evaluasi) untuk Mensukseskan Pembelajaran Daring pada Masa Pandemi Covid 19.

Penelitian dilaksanakan di SDN Plosojenar Kecamatan Jakenan Kabupaten Pati Provinsi Jawa Tengah. SDN Plosojenar dipilih sebagai tempat penelitian karena peneliti sebagai kepala sekolah di sekolah tersebut yang baru mutasi kurang lebih satu bulan dan harus melaksanakan kebijakan pemerintah untuk menyelenggarakan pembelajaran daring pada masa pandemi Covid-19.

Waktu penelitian selama empat bulan yakni mulai bulan Maret sampai dengan Juni 2020 pada semeser genap tahun pelajaran 2019/2020 dengan subyek penelitian yang terdiri dari peserta didik, guru, orang tua siswa, komite sekolah, masyarakat dan jajaran dinas pendidikan.

Metode penelitian yang digunakan adalah metode studi kasus. Studi kasus menurut Sukmadinata (2012: 64) merupakan suatu penelitian yang dilakukan terhadap suatu kesatuan sistem baik berupa program, kegiatan, peristiwa, atau sekelompok individu yang terikat oleh tempat, waktu atau ikatan tertentu. Metode ini dipilih karena rumusan masalah penelitian ingin mengungkap tentang perencanaan, pelaksanaan, dan evaluasi penyelenggaraan DIPARE di 
SDN Plosojenar yang nantinya akan bermuara pada pencapaian pembelajaran yang sesuai dengan visi dan misi sekolah.

Teknik pengumpulan datanya menggunakan teknik wawancara, observasi dan studi dokumen. Data yang telah terkumpul selanjutnya dianalisis dan diinterpretasikan, sehingga diharapkan penelitian ini akan memberikan gambaran utuh dari penyelenggaraan DIPARE sebagai terobosan agar pembelajaran pada masa pandemi Covid-19 ini tetap berjalan baik di SDN Plosojenar. Adapun tahapan atau langkah-langkah dalam pemecahan masalah yang dihadapi dalam mensukseskan pembelajaran daring dengan pemberdayaan DIPARE (Diskusi, Inovasi, Partisipasi, Akuntabel, Reward, dan Evaluasi) adalah sebagai berikut:

1. Melakukan diskusi yang dimotori oleh kepala sekolah bersama warga sekolah untuk mengatasi permasalahan-permasalahan yang ditemui dalam pembelajaran daring.

2. Mengadakan inovasi dengan pelatihan dan bimbingan dalam menggunakan berbagai aplikasi pembelajaran daring.

3. Mendorong partisipasi dari semua warga sekolah terutama guru, pengawas sekolah, orang tua siswa dan tim ahli untuk mengatasi masalah-masalah yang timbul dalam pembelajaran daring.

4. Pelaporan secara akuntabel baik administrasi pembelajaran, pelaksanaan pembelajaran, maupun pembiayaan dalam kegiatan tersebut.

5. Memberikan reword atau hadian kepada warga sekolah yang berperan secara aktik dan menjadi motor penggerak suksesnya pembelajaran daring dan program-program sekolah lainnya.

6. Mengadakan evaluasi dari program yang sudah dilaksanakan sebagai bahan perbaikan untuk program yang akan datang.

\section{HASIL DAN PEMBAHASAN}

Pemberdayaan DIPARE merupakan kegiatan manajemen sekolah yang diterapkan oleh Kepala Sekolah untuk pengembangan sekolah dengan tahapan diskusi, inovasi, partisipasi, akuntabel, reword, dan evaluasi. Pemberdayaan DIPARE dipilih oleh Kepala Sekolah selaku pengelola manajemen sekolah sebagai solusi adanya pandemi Covid-19 di mana kegiatan pembelajaran dilakukan secara daring agar kegiatan belajar mengajar tetap berjalan maksimal, sehingga memunculkan kwalitas pendidikan berjalan sesuai visi dan misi yang sudah diterapkan.

Strategi pemecahan masalah yang dihadapi di SD Negeri Plosojenar dilakukan dengan menerapkan pemberdayaan DIPARE untuk mensukseskan pembelajaran daring pada masa pandemi Covid-19. Fokus utama dalam kegiatan ini adalah pengelolaan sumber daya yang ada di sekolah secara optimal bagi pendidik dan peserta didik, orangtua, komite sekolah, dan masyarakat. Kepala sekolah mengoptimalkan peran warga sekolah dalam memberikan kontribusi positif dalam mendukung terlaksananya pembelajaran daring yang efektif dan efisien serta berkwalitas.

\section{Hasil}

Upaya yang ditempuh dalam mensukseskan pembelajaran daring pada masa pandemi Covid-19 ini dapat dipaparkan sebagai berikut.

\section{Diskusi}

Kepala sekolah sebagai manajer di SD Negeri Plosojenar berupaya mengoptimalkan sumber daya yang ada di lingkungan sekolah dalam musyawarah atau diskusi dalam mencari solusi dan alternatif dalam pengembangan strategi pembelajaran yang dapat dilakukan pada masa pandemi Covid-19. Upaya mengikutsertakan semua warga sekolah dalam perencanaan yaitu dengan musyawarah antara guru, orang tua siswa (tiap-tiap kelas diwakili oleh tiga orang tua/wali peserta didik), komite, serta pengawas sekolah yang mendukung suksesnya pelaksanaan pembelajaran daring pada masa pandemi ini. 
Dalam musyawarah atau diskusi ini, kepala sekolah selaku manajer menjembatani jalannya diskusi warga sekolah dalam menggali hambatan-hambatan yang dialami oleh warga sekolah terutama guru dan wali murid, serta hambatan-hambatan yang dialami siswa dalam pembelajaran daring guna menemukan solusi dari masalah tersebut. Kepala sekolah menampung apa yang disampaikan oleh guru dan orang tua siswa, kemudian diskusi dilanjutkan dengan mencari solusi dan pemecahan dari permasalah tersebut dengan mempertimbangkan berbagai faktor dan kemungkinan yang terjadi. Komite sekolah dan pengawas memberikan tanggapan dan juga masukan yang dapat digunakan sebagai alternatif pemecahan masalah yang dihadapi.

Berikut salah satu upaya untuk memfasilitasi semua pihak dalam upaya mencari solusi dan alternatif pengembangan pembelajaran pada masa pandemi Covid-19 di SD Negeri Plosojenar.
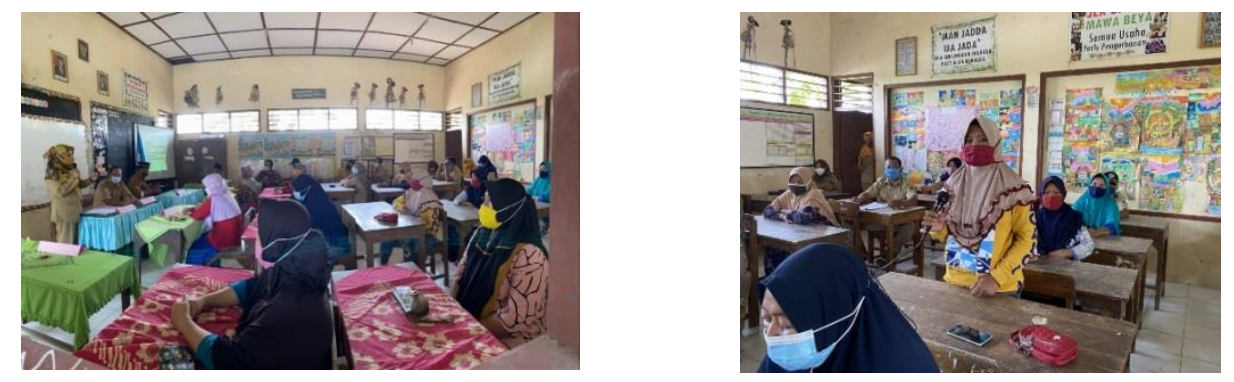

\section{Gambar 1-2. Kegiatan diskusi dengan warga sekolah terkait pembelajaran daring}
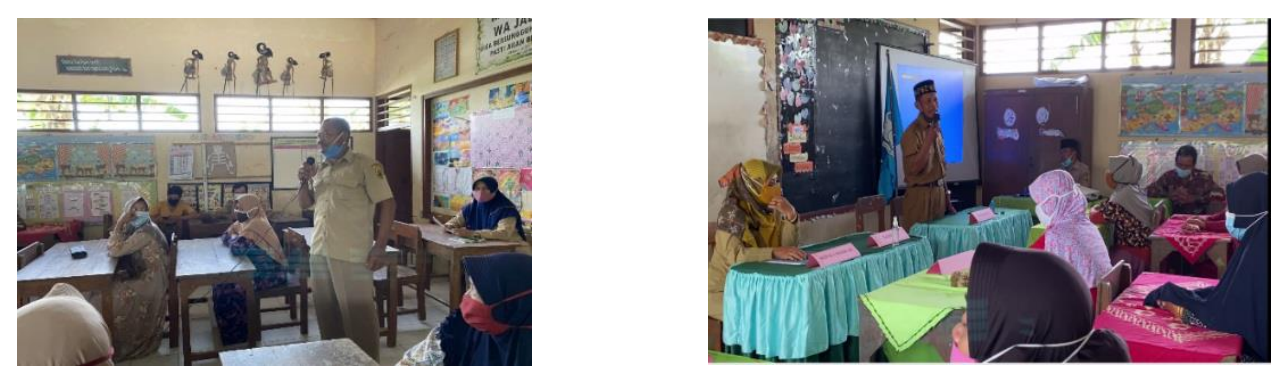

Gambar 3-4. Partisipasi warga sekolah dalam kegiatan diskusi terkait pembelajaran daring

\section{Inovasi}

Dalam rangka menghadapi tantangan, dan problema pendidikan khususnya bagaimana membangun visi, menggeser paradikma dan menyesuaikan kerangka kerja, kepala sekolah berupaya meningkatkan mutu dalam proses pembelajaran yang dilakukan dengan pembinaan guru secara terus menerus terutama terkait peningkatan mutu pendidikan pada masa pandemi Covid-19 agar tetap terjaga kwalitas pembelajaran dan layanan pendidikan untuk siswa. Dalam hal ini inovasi dan leadership (kepemimpinan) seorang kepala sekolah sangat diharapkan agar mampu menciptakan suasana dan ekosistem yang baik di lingkungan sekolah dan juga sekitarnya yakni melalui pelatihan penggunaan aplikasi pembelajaran daring mulai dari menggunakan aplikasi Wattsap, Zoom Meeting, Google Classroom, Google Meet, sampai pada pembuatan media pembelajaran, serta video pembelajaran dan pemberian bimbingan serta diskusi mengenai cara mengatasi permasalahan dalam pembelajaran daring.

Melalui kegiatan pelatihan dan bimbingan serta diskusi tersebut, guru-guru mendapatkan pengalaman baru yang mendukung dalam kegiatan belajar mengajar.

Inovasi yang dilakukan oleh kepala sekolah selaku manajer sekolah mendapat sambutan baik dari para guru dan orang tua siswa, pembelajaran yang dulunya hanya memberikan tugas kepada siswa lewat aplikasi Wattsap kini sudah mulai menggunakan berbagai aplikasi yang dapat mendukung proses pembelajaran. 

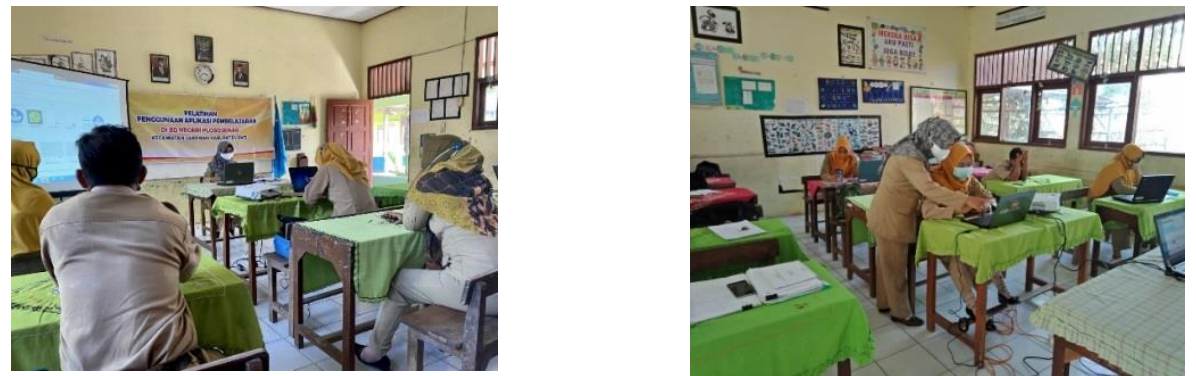

\section{Gambar 5-6. Kegiatan pelatihan dan pendampingan sebagai inovasi terkait} pembelajaran daring

\section{Partisipasi}

Kepala sekolah SD Negeri Plosojenar selaku manajer berupaya mengikutsertakan semua warga sekolah mulai dari guru, orang tua siswa, komite dan pengawas dalam semua perencanaan maupun kegiatan dengan musyawarah untuk menentukan kebijakan sekolah yang mendukung terciptanya proses belajar mengajar terutama pada masa pandemi Covid-19.

Hal paling penting untuk diterapkan oleh kepala sekolah dalam langkah ini adalah bagaimana membuat guru untuk berani berpartisipasi, baik sebagai peserta yang aktif maupun sebagai pemateri. Keberanian yang memang bukan tumbuh dengan sendirinya, tetapi perlu dorongan terutama dari kepala sekolah sebagai pimpinan. Pada tahap awal, kepala sekolah memberikan contoh tentang bagaimana menjadi narasumber, sedangkan tahap selanjutnya guru didorong untuk memiliki keberanian dan kepercayaan diri untuk tampil.

Partisipasi aktif maupun pasif guru dalam memberikan bimbingan dan arahan kepada teman sejawat dalam memberikan solusi pembelajaran daring agar efektf dan efisien serta menyenangkan bagi siswa.
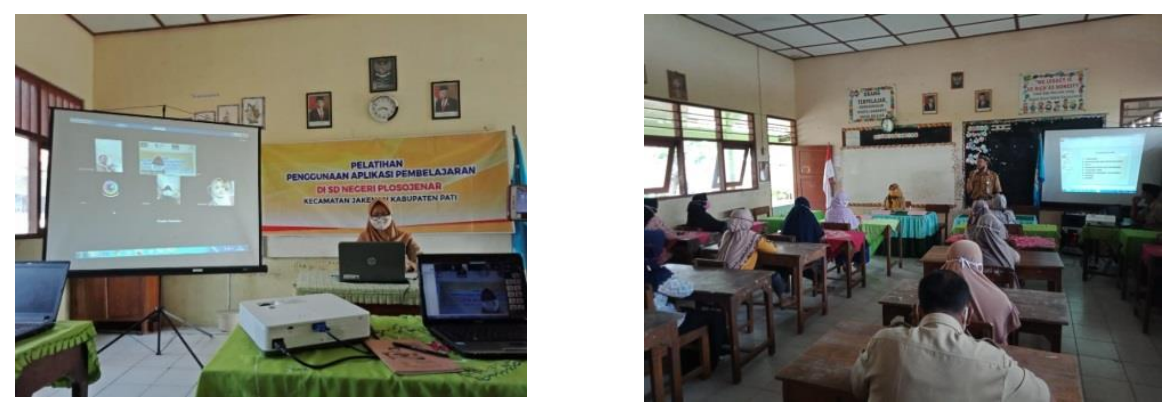

\section{Gambar 7-8. Kegiatan sambung rasa dengan warga sekolah pembelajaran daring}

Melalui kegiatan-kegiatan musyawarah dimanfaatkan oleh kepala sekolah dalam mengatur alur komunikasi sehingga tetap berjalan dengan lancar serta menjamin bahwa kegiatan dalam proses belajar mengajar tetap mengarah pada tujuan yang ditetapkan. Kepala sekolah juga berperan sebagai role model bagi spirit dalam melakukan perbaikan pembelajaran terutama bagi guru.

Meningkatnya kompetensi profesional dan pedagogik telah berdampak terhadap meningkatnya pemahaman guru mengenai berbagai program sekolah sehingga partisipasi guru pada program-program tersebut meningkat. Hal ini akan berimbas pada peningkatan mutu pembelajaran serta peningkatan hasil belajar siswa.

Program-program yang telah disusun dalam musyawarah bersama warga sekolah kemudian disosialisasikan kepada semua warga sekolah dan orang tua untuk dilaksanakan dengan partisipasi semua pihak. Program tersebut juga tercantum dalam rencana kerja sekolah, yang dijabarkan dalam komponen-komponen yang jelas serta sumber pendanaannya.

Peran partisipasi warga sekolah terutama orang tua siswa sangat berperan penting bagi kelancaran proses kegiatan belajar mengajar daring. Dari partisipasi itu orang tua siswa juga 
mendapatkan pengetahuan tentang berbagai macam aplikasi yang digunakan oleh guru dalam kegiatan belajar mengajar, sehingga orang tua siswa dapat mengarahkan siswa ketika mengikuti kegiatan belajar di rumah.

Partisipasi warga sekolah dalam musyawarah guna memajukan sekolah dan mencari solusi atas permasalahan-permasalahan yang terjadi dalam proses pembelajaran daring dapat dilihat dalam kegiatan berikut.
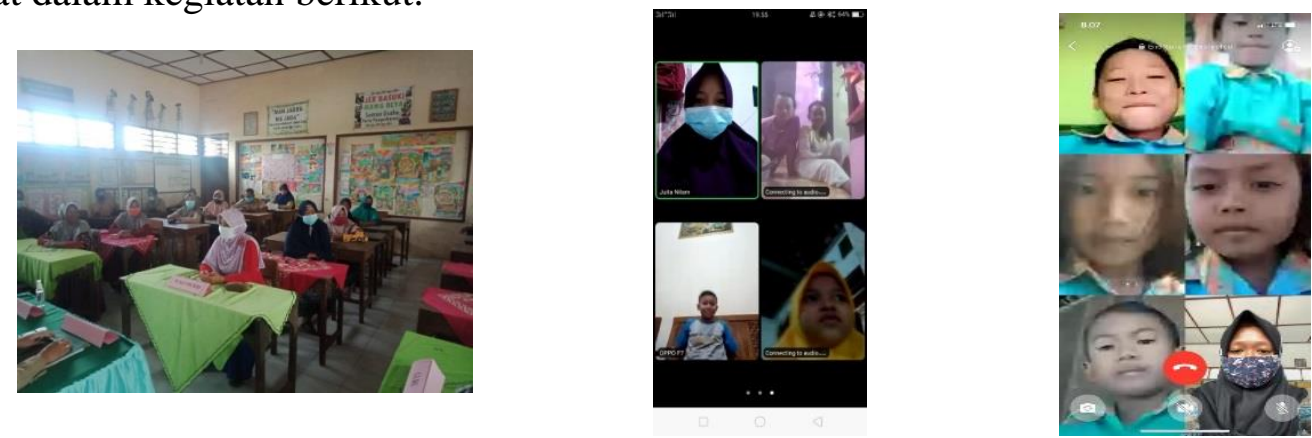

Gambar 9-10. Partisipasi warga sekolah musyawarah serta pendampingan siswa dalam pembelajaran daring

\section{Akuntabel}

Semua kegiatan yang berkaitan dengan pembelajaran daring dilaporkan secara akuntabel yakni terbuka dan transparan. Baik laporan administrasi maupun keuangan yang mendukung keterlaksanaan pembelajaran daring dilakukan secara rutin dan berkala.

Kegiatan guru mulai dari perencanaan dan pelaksanaan pembelajaran dilaporkan kepada kepala sekolah dalam bentuk RPP daring dan kegiatan pembelajaran daring. Pelaporan tersebut kemudian dianalisis oleh kepala sekolah beserta teman sejawat guna menimbang kesesuaian materi serta aplikasi yang digunakan serta kesesuaian materi dengan langkah-langkah pembelajaran yang akan diterapkan.

Pemanfaatan keuangan sekolah guna menunjang berjalannya kegiatan administrasi serta pendukung pembelajaran dilaporkan secara detail dan transparan disertai bukti-bukti yang akurat. Pelaporan ini dilakukan secara tertulis dan disampaikan kepada semua pihak yang bersangkutan. Hal ini sebagai bentuk pertanggungjawaban kepada semua pihak untuk mendapat kepercayaan warga sekolah.
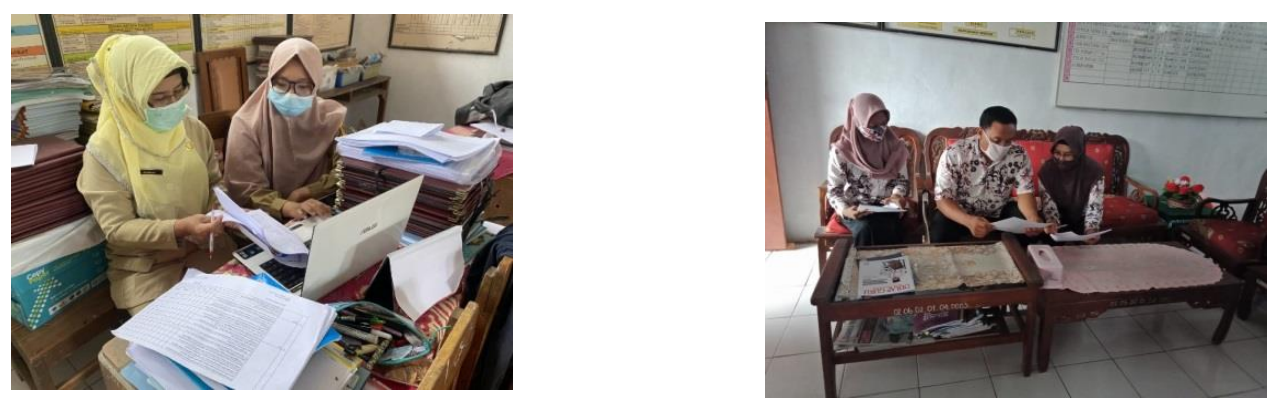

\section{Gambar 11-12. Kegiatan pelaporan RPP dan analisis langkah-langkah pembelajaran daring}

\section{Reward}

Pemberian reward dilakukan untuk menghargai segala aktivitas yang telah dilakukan baik oleh guru maupun siswa ataupun warga sekolah yang lain sebagai penghargaan atas upayanya dalam memajukan sekolah dan berkontribusi dalam kelancaran pembelajaran daring pada masa pandemi Covid-19. Hal ini, akan memberikan kesan bahwa apa yang dilakukan warga sekolah tidak sia-sia. Reward juga diberikan kepada siapa saja yang menjadi motor atau penggerak inovasi dalam meningkatkan kwalitas pendidikan di SD Negeri Plosojenar. Selain itu, reward juga diberikan kepada siswa-siswa yang memperoleh juara pada kegiatan perlombaan. 
Pemberian penghargaan bisa menjadi motivasi yang luar biasa bagi guru untuk terus berkarya. Pemberian penghargaan terhadap kinerja guru bisa dilakukan dengan berbagai cara, misalnya dengan pujian, maupun dengan pemberian kesempatan kepada guru untuk menjadi narasumber kegiatan. Perasaan dihargai sebagai guru, ditempatkan sebagai manusia yang memiliki kemampuan memberikan energi yang luar biasa bagi guru untuk berbuat lebih baik.
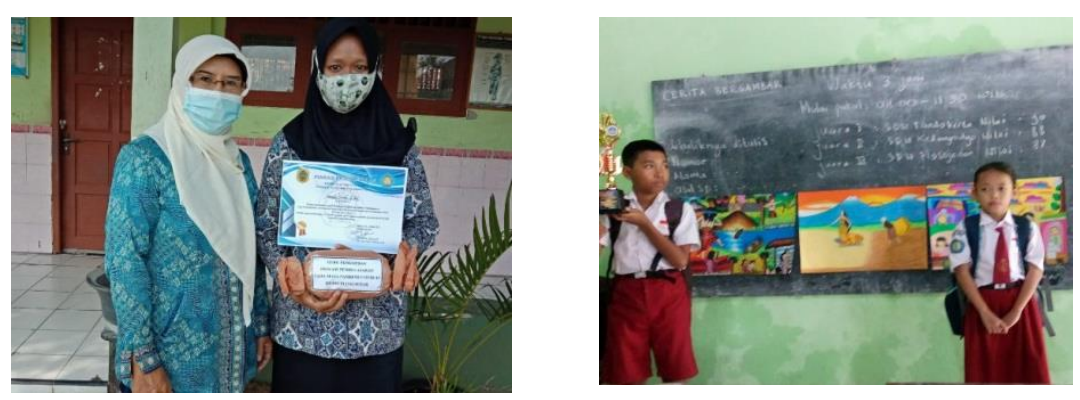

Gambar 13-14. Pemberian reward (hadiah) bagi guru dan siswa

Tak hanya yang disebutkan di atas, sekolah juga meberikan reward bagi tim yang menghasilkan ide, gagasan, atau produk yang dapat mendorong bagi warga sekolah yang lain untuk mencari inovasi-inovasi baru dalam memajukan sekolah terutama yang berkaitan dalam kegiatan belajar mengajar.

\section{Evaluasi}

Pada tahap akhir program dilaksanakan evaluasi. Evaluasi dilaksanakan melalui forum diskusi dewan guru berdasarkan catatan pengamatan, dokumentasi prestasi, dan kendalakendala yang dihadapi selama proses berlangsung. Hasil evaluasi digunakan sebagai bahan untuk menentukan rencana tindak lanjut.

Hasil evaluasi dijadikan acuan rencana tindak lanjut untuk pengembangan berikutnya. Monitoring dilakukan dengan mengamati seberapa besar pengaruh program DIPARE dalam mensukseskan pembelajaran daring pada masa pandemi Covid-19. Monitoring secara berkala dilakukan agar tingkat ketercapaian program dapat dioptimalkan dan berkelanjutan.

Evaluasi juga dilakukan secara kualitatif dengan memberikan tanggapan terhadap proses dan hasil kegiatan. Proses evaluasi dilakukan kepada semua warga sekolah. Evaluasi dan tindak lanjut dalam bentuk laporan umpan balik. Evaluasi dan umpan balik ini didapat dari semua warga sekolah. Evaluasi dan umpan balik dalam bentuk kuesioner mengenai hasil dan implementasi program DIPARE di SD Negeri Plosojenar. Serta saran dan masukan dari guru dan tenaga kependidikan serta warga sekolah lainnya untuk kelanjutan program atau masukan untuk gagasan program lainnya di masa depan.

Setelah semua kegiatan dilaksanakan, maka akan dianalisis tingkat keberhasilan dan kekurangannya. Kekurangan dan kendala-kendala yang muncul akan digunakan untuk mencari solusi berikutnya.

\section{Hasil yang dicapai dari pemberdayaan kegiatan DIPARE}

Pemberdayaan kegiatan DIPARE (diskusi, inovasi, partisipasi, akuntabel, reward, dan evaluasi) memiliki dampak yang luar biasa, berbagai inovasi dalam kegiatan belajar mengajar, berbagai penggunaan aplikasi dalam pembelajaran, motivasi belajar siswa yang meningkat, serta peran dan antusias warga sekolah yang membanggakan.

Berdasarkan hasil pembinaan, pemantauan, pengamatan, dan wawancara terhadap pemberdayaan kegiatan DIPARE mensukseskan pembelajaran daring pada masa pandemi Covid-19, capaian yang diperoleh dari dampak pelaksanaan program DIPARE dapat diuraikan sebagai berikut: 
1. Terbangunnya kerja sama warga sekolah dalam menghadapi kendala-kendala pembelajaran daring pada masa pandemi Covid-19. Hal ini ditandai dengan antusias dan partisipasi semua warga sekolah dalam mendukung program-program sekolah. Warga sekolah baik kepala sekolah, guru, orang tua siswa, komite sekolah, bahkan pengawas berperan aktif dalam mensukseskan kegiatan tersebut, mulai dari menjadi peserta pasif sampai menjadi peserta aktif yang menjadi motor atau penggerak bagi warga sekolah lain dalam mengembangkan berbagai metode dan penggunaan aplikasi pembelajaran daring. Hasil pengamatan juga menunjukkan bahwa sejak program pelaksanaan DIPARE kesadaran guru tentang pentingnya inovasi-inovasi dalam pembelajaran meningkat. Hal ini dapat dilihat dari topik pembicaraan guru lebih mengarah pada hal-hal yang ada relevansinya dengan tugas fungsi guru. Indikasi lainnya yang berhubungan dengan motivasi belajar adalah masuknya guru pada komunitas PKB on line Rumah Belajar yang berjalan di bawah naungan kemdikbud.

2. Kompetensi profesional dan pedagogik guru meningkat, yaitu yang berkaitan dengan penguasaan IT, penyusunan KTI berupa PTK, dan penggunaan berbagai aplikasi pembelajaran.

3. Sebagian besar guru telah menerapkan aplikasi-aplikasi pembelajaran daring seperti:

a. Aplikasi Wattsap

Aplikasi Wattsap menjadi pilihan yang sesuai dalam pembelajaran daring sekarang ini. Penggunaan aplikasi ini juga sangat simpel dan mudah operionalnya sehingga siswa dan orang tua siswa tidak kesulitan memanfaatkan aplikasi ini. Penggunaan aplikasi ini dapat dilihat pada gambar di bawah ini,
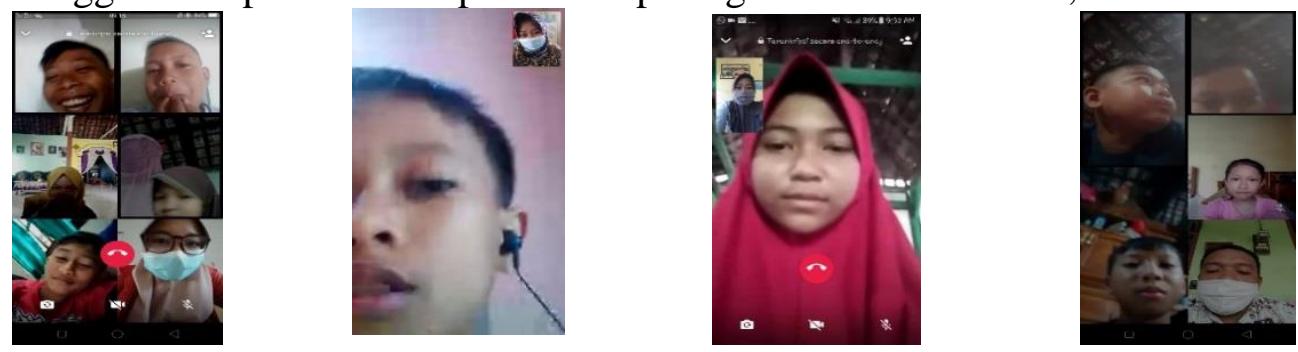

Gambar 15. Pelaksanaan pembelajaran melalui aplikasi Wattsap

b. Zoom Meeting

Aplikasi ini memudahkan guru dalam memberikan materi tanpa harus tatap muka secara langsung. Guru dapat memantau aktivitas dan motivasi belajar siswa melalui aplikasi ini dengan memperhatikan sikap dan kesiapan siswa saat proses belajar mengajar berlangsung.
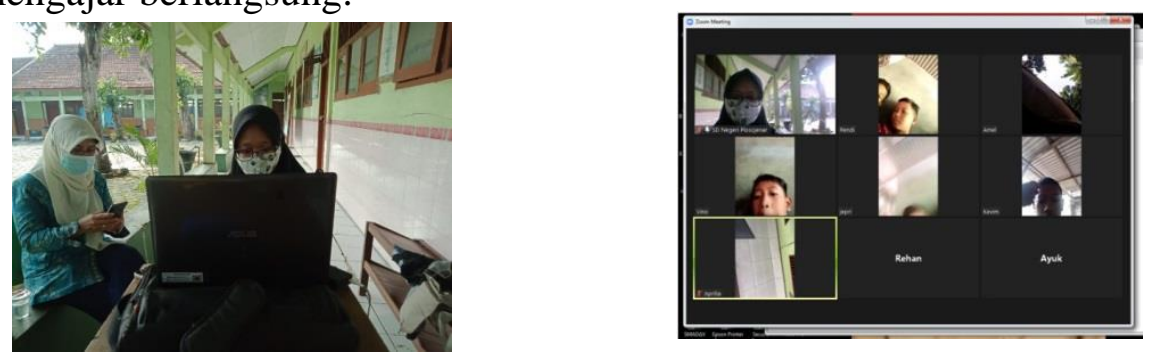

Gambar 15. Pelaksanaan pembelajaran melalui aplikasi zoom meeting

c. Google Classroom

Google Classroom (atau dalam bahasa Indonesia yaitu Ruang Kelas Google) adalah suatu aplikasi pembelajaran campuran yang diperuntukkan terhadap setiap ruang lingkup pendidikan untuk menemukan jalan keluar atas kesulitan dalam membuat, membagikan dan menggolong-golongkan setiap penugasan tanpa kertas.

Aplikasi ini membantu pengajar untuk membuat dan mengatur tugas dengan cepat, memberi masukan secara efisien, dan berkomunikasi dengan mudah dengan kelasnya. 
d. Google Meet

Google Meet merupakan salah satu dari sekian banyak aplikasi video telekonferensi. Layanan ini mampu menampung sekitar 100 orang dalam satu sesi rapat virtual. Penggunaan google meet sama seperti zoom yaitu sama-sama dapat bertatap muka langsung antara guru dan siswa untuk melakukan kegiatan belajar mengajar. Menariknya, pengguna bisa menggunakan layanan Meet secara cuma-cuma baik melalui aplikasi desktop (PC/laptop) maupun HP Android.

Berangkat dari inovasi yang dilakukan oleh kepala sekolah, pembelajaran yang dilakukan oleh guru sedikit demi sedikit sudah berubah, guru mulai terbiasa menciptakan inovasi baru dalam proses pembelajaran, mulai dari menggunakan aplikasi Wattsap, Zoom Meeting, Google Classroom, Google Meet, sampai pada pembuatan media pembelajaran, serta video pembelajaran yang berakibat pada meningkatnya motivasi siswa dan hasil belajar siswa. Peningkatan hasil belajar siswa dapat dilihat pada tabel dan pada grafik berikut ini.

Tabel 1. Hasil Perolehan Nilai US SDN Plosojenar

\begin{tabular}{|c|c|c|}
\hline No & Tahun Pelajaran & Hasil US \\
\hline 1 & $2019 / 2020$ & 85,06 \\
\hline 2 & $2020 / 2021$ & 86,61 \\
\hline
\end{tabular}

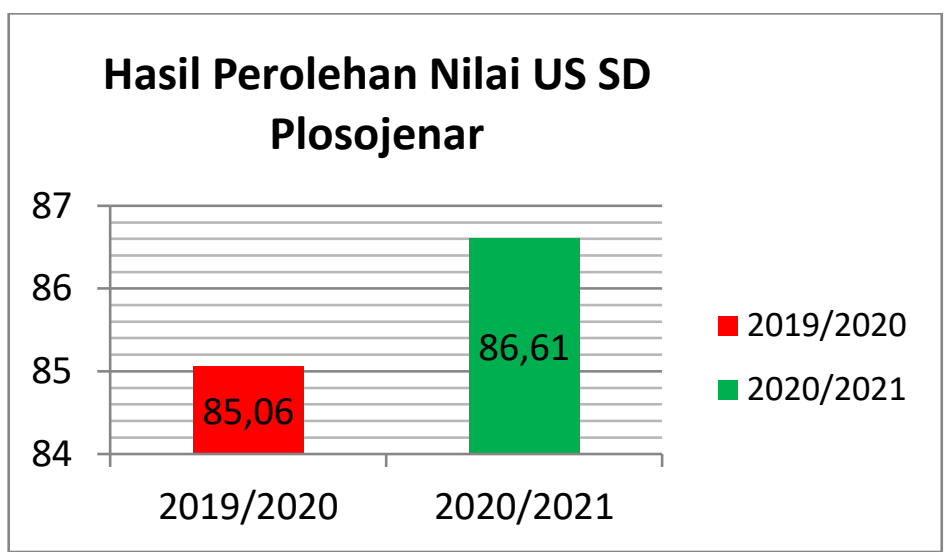

Gambar 1. Diagram Hasil Perolehan Nilai US SDN Plosojenar

Tabel 2. Capaian Nilai Tarap Serap Kurikulum

\begin{tabular}{|c|c|c|c|}
\hline No & Tahun Pelajaran & Semester 1 & Semester 2 \\
\hline 1 & $2019 / 2020$ & 77 & 78 \\
\hline 2 & $2020 / 2021$ & 80 & 81 \\
\hline
\end{tabular}

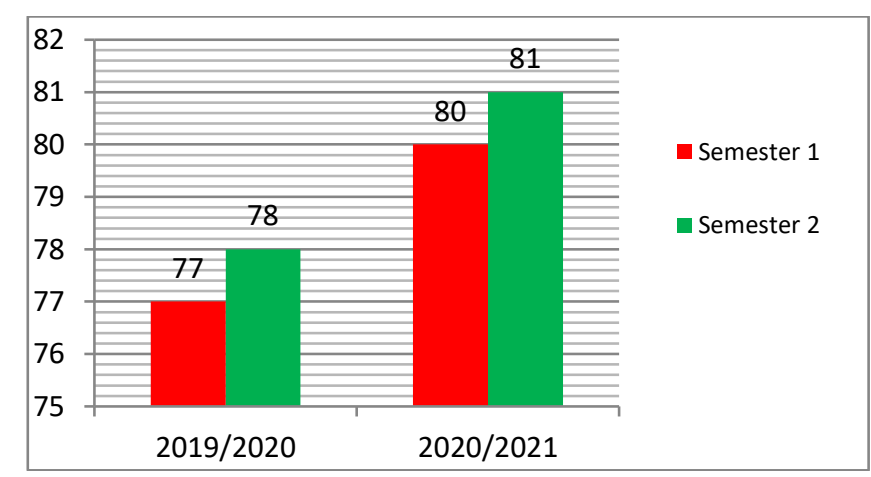

Gambar 2. Diagram Capaian Nilai Tarap Serap Kurikulum

4. Sebagian guru sudah membuat media pembelajaran sendiri serta video pembelajaran. Dengan pemberdayaan kegiatan DIPARE memberikan pengetahuan baru bagi guru-guru SD Negeri Plosojenar yang tadinya hanya mendownlod video pembelajaran dari youtube, 
sekarang sudah mulai membuat video pembelajaran sendiri yang disesuaikan dengan materi dan kebutuhan siswa.

5. Pemenuhan perangkat pembelajaran mencapai $98 \%$ pada tahun pelajaran 2020/2021.

6. Hasil wawancara dengan guru menunjukan bahwa, $100 \%$ guru memahami dan menyatakan bahwa pemberdayaan kegiatan DIPARE sangat bermanfaat bagi pengembangan kompetensi, merasa dihargai dengan diberikan kesempatan untuk berbagi pengetahuan, dan pengadaan pelatihan serta pendampingan yang dilakukan oleh kepala sekolah selaku manajer sekolah dapat menambah ilmu dan pengetahuan baru.

\section{Pembahasan}

Kegiatan diskusi yang merupakan kegiatan awal dari pemberdayaan DIPARE merupakan usaha kepala sekolah untuk mengoptimalkan sumber daya yang ada di lingkungan sekolah untuk mencari solusi dan alternatif dalam pengembangan strategi pembelajaran yang dapat dilakukan pada masa pandemi covid-19. Kegiatan ini dimanfaatkan oleh warga sekolah baik guru maupun orang tua siswa untuk menyampaikan hambatan-hambatan yang dialaminya dalam membimbing siswa baik di sekolah maupun di rumah. Hambatan- hambatan yang disampaikan oleh guru maupun orang tua siswa ditampung oleh kepala sekolah dan selanjutnya dicari solusi dan pemecahannya bersama pengawas sekolah dan komite dengan mempertimbangkan berbagai faktor dan kemungkinan yang terjadi sampai akhirnya ditemukan solusi pemecahan dan disepakati bersama. Dengan demikian sudah tidak ada lagi hambatanhambatan atau kendala-kendala yang dialami guru maupun orang tua siswa dalam membimbing siswa atau anak di rumah dan pembelajaran daring pada masa pandemi bisa sukses.

Dalam rangka meningkatkan mutu pembelajaran pada masa pandemi covid-19 kepala sekolah memberikan pembinaan guru secara terus menerus agar tetap terjaga kwalitas pembelajaran dan layanan pendidikan untuk siswa yakni dengan memberikan inovasi baru dalam pembelajaran melalui pelatihan dan bimbingan penggunaan aplikasi pembelajaran daring. Inovasi yang dilakukan kepala sekolah ini mendapat sambutan baik dari para guru dan orang tua siswa. Pembelajaran yang dulunya hanya memberikan tugas kepada siswa lewat aplikasi WhatsApp, kini sudah mulai menggunakan berbagai aplikasi baik WhatsApp, Zoom Meeting, Google Classroom, Google Meet, sampai pada pembuatan media pembelajaran dan vidio pembelajaran yang dapat mendukung proses pembelajaran dan berakibat meningkatnya motivasi dan hasil belajar siswa. Hal ini sejalan dengan pengalaman kisah sukses atau Best Practice yang dilakukan Surjono, H.D. (2018) sekaligus sebagai rujukan pada Best Practice ini. Dari pengalaman yang diterapkan maka diambil kesimpulan bahwa dalam pembelajaran harus mulai menerapkan e-learning/online corse untuk menyikapi kebijakan pemerintah terkait pembelajaran pada masa pandemi ini. Selain itu beliau memaparkan bahwa pembelajaran daring perlu dirancang sedemikian rupa sehingga pembelajaran tidak membosankan, siswa tetap antusias meski pembelajaran dilakukan dengan cara daring. Maka dari itu pendidik harus ekstra kerja keras demi memenuhi kebutuhan pembelajaran pada masa pandemi ini. Perlu dirancang model pembelajaran serta aplikasi yang akan digunakan dalam pembelajaran.Kendala implementasi e-learning yang dialami dapat diatasi melalui usaha bersama BAKI, LPPMP, Puskom, dan pelatihan para pendidik.

Kesuksesan pembelajaran daring pada masa pandemi covid-19 di SD Negeri Plosojenar tak lepas dari dukungan berbagai fihak baik guru, orang tua siswa, komite dan pengawas sekolah. Mulai dari perencanaan, pelaksanaan sampai pada penentuan kebijakan sekolah yang mendukung terciptanya proses pembelajaran daring, semua melibatkan warga sekolah. Partisipasi aktif maupun pasif guru dalam memberikan bimbingan dan arahan kepada teman sejawat dalam memberikan solusi pembelajaran daring agar efektif dan efisien serta menyenangkan bagi siswa. Peran orang tua siswa juga tak kalah penting bagi kelancaran proses kegiatan belajar daring karena mendampingi dan mengarahkan anaknya ketika belajar di rumah. Dengan partisipasi semua warga sekolah maka akan terbangun kerja sama yang baik dalam mensuksekan pembelajaran daring pada masa pandemi covid-19. 
Semua kegiatan yang berkaitan dengan pembelajaran daring dilaporkan secara akuntabel yakni terbuka dan transparan, baik laporan administrasi maupun keuangannya. Mulai dari kegiatan perencanaan dan pelaksanaan pembelajaran daring dilaporkan guru kepada kepala sekolah untuk dianalisis bersama teman sejawat guna menimbang kesesuaian materi dan aplikasi yang digunakan dengan langkah-langkah pembelajaran yang akan diterapkan. Pemanfaatan keuangan sekolah untuk menunjang pembelajaran daring juga dilaporkan secara detail dan transparan yang disertai bukti-bukti yang akurat serta disampaikan kepada semua fihak yang bersangkutan. Hal ini sebagai bentuk pertanggungjawaban kegiatan yang telah dilakukan untuk mendapatkan kepercayaan warga sekolah. Dengan kepercayaan ini maka tidak ada ganjalan dalam melaksanakan pembelajaran daring. Pembelajaran daring pada masa pandemi berjalan aman, nyaman, menyenangkan dan sukses.

Untuk menghargai segala aktivitas yang dilakukan oleh guru maupun siswa ataupun warga sekolah yang lain, maka kepala sekolah memberikan reward atau penghargaan atas upaya memajukan sekolah melalui kontribusi dalam kelancaran pembelajaran daring pada masa pandemi covid-19. Hal ini memberikan kesan bahwa apa yang dilakukan warga sekolah tidak sia-sia dan menjadi motivasi yang luar biasa bagi guru untuk terus berkarya dan bagi siswa untuk terus meningkatkan belajarnya karena merasa senang telah dihargai. Adapun bentuk penghargaan yang diberikan, tidak hanya berupa materi namun juga berupa pujian atau pemberian kesempatan kepada guru untuk menjadi narasumber kegiatan. Perasaan dihargai sebagai guru, ditempatkan sebagai manusia yang memiliki kemampuan dan memberikan energi yang luar biasa untuk berbuat yang lebih baik. Dengan dilandasi semangat dan motivasi ini maka pelaksanaan pembelajaran daring pada masa pandemi covid-19 akan lebih bermakna.

Hal itu sejalan dengan apa yang ungkapkan oleh Ngalim Purwanto (1985: 231) bahwa reward merupakan pemberian atau balasan suatu kepada seseorang sebagai penghargaan karena melakukan aktivitas sesuai denga perbuatannya, baik dari segi kualitas maupun dari segi kuantitas dan balasan itu dapat menghasilkan kepuasan atau menambah kemungkinan untuk berbuat lebih baik lagi dan reward juga salah satu alat pendidikan. Jadi dengan sendirinya maksud ganjaran itu ialah sebagai alat untuk memicu warga sekolah supaya dapat merasa senang karena perbuatannya atau pekerjaannya mendapatkan penghargaan.

Evaluasi merupakan tahap akhir dari pelaksanaan program DIPARE. Evaluasi dilaksanakan melalui forum diskusi dewan guru berdasarkan catatan pengamatan, dokumen prestasi dan kendala-kendala yang dihadapi selama proses berlangsung yang hasilnya akan digunakan untuk acuan menentukan rencana tindak lanjut. Monitoring dilakukan secara berkala dan berkelanjutan dengan mengamati seberapa besar pengaruh program DIPARE dalam mensukseskan pembelajaran daring pada masa pandemi covid-19 agar tingkat ketercapaian program dapat dioptimalkan. Proses evaluasi dilakukan kepada semua warga sekolah dalam bentuk laporan umpan balik terhadap proses dan hasil kegiatan. Saran dan masukan dari warga sekolah digunakan sebagai pertimbangan untuk kelanjutan program lainnya di masa depan.

Pemberdayaan kegiatan DIPARE selain memberikan hasil sebagaimana diuraikan di atas, juga memberikan dampak terhadap guru, peserta didik dan sekolah. Dampak terhadap guru adalah mendapatkan pengetahuan baru tentang aplikasi pembelajaran daring yang dapat digunakan untuk memaksimalkan proses belajar mengajar pada masa pandemi covid-19. Dampak lainnya nilai PKB guru-guru SDN Plosojenar pada tahun 2020 mendapat predikat "Baik". Nilai rata-rata Ujian Sekolah yang diperoleh peserta didik terjadi kenaikan yang siknifikan, yaitu 85,06 pada tahun pelajaran 2019/2020 naik menjadi 86,61 pada tahun pelajaran 2020/202. Kenaikan juga terjadi pada pencapaian nilai taraf serap kurikulum. Pada tahun pelajaran 2019/2020 nilai taraf serapnya 77 dan 78 pada semester 1 dan 2, meningkat menjadi 80 dan 81 pada tahun pelajaran 2020/2021.

Dampak pemberdayaan DIPARE terhadap sekolah adalah meningkatnya kompetensi profesional dan pedagogic, meningkatnya pemahaman guru mengenai berbagai program sekolah lainnya dan meningkatnya partisipasi guru pada perencanaan dan pelaksanaan 
program-program lainnya. Hal ini berimbas pada peningkatan mutu pendidikan di SD Negeri Plosojenar.

Pemberdayaan DIPARE dipercaya dapat mewujudkan pembelajaran daring yang efektif dan efisien untuk kemajuan SD Negeri Plosojenar. Dengan kegiatan tersebut diharapkan siswa mendapatkan pelayanan pembelajaran yang maksimal sehingga out put ke depannya lebih berkwalitas dan unggul serta dapat melanjutkan sekolah yang lebih tinggi sesuai dengan harapan dengan nilai yang membanggakan.

\section{KESIMPULAN}

Berdasarkan uraian di atas, penyelenggaraan kegiatan DIPARE terbukti mampu mensukseskan pembelajaran daring pada masa pandemi COVID-19 serta meningkatkan kompetensi profesional dan pedagogik guru SD Negeri Plosojenar. Penyelenggaraan kegiatan DIPARE dapat digunakan oleh kepala sekolah lainnya yang tertarik untuk mengaplikasikan strategi ini sesuai dengan kondisi sekolah masing-masing. Beberapa rekomendasi dapat diuraikan sebagai berikut.

1. Pada kegiatan diskusi perlu diadakan diskusi yang lebih intensif dengan pembentukan kelompok-kelompok kecil guru kelas agar diskusi berjalan lebih maksimal.

2. Pada kegiatan inovasi, perlu ditambahkan dengan keterlibatan ahli misalnya pengawas sekolah, atau unsur-unsur dari kalangan ahli di bidangnya, sehingga ilmu yang diserap lebih banyak dan profesionalitas dapat lebih ditingkatkan.

3. Pada langkah partisipasi, kepala sekolah harus memberikan porsi yang lebih besar kepada guru untuk meningkatkan self-belonging mereka terhadap program kegiatan, sehingga tingkat ketercapaian program dapat lebih ditingkakan lagi.

4. Meningkatkan pengetahuan tentang seni-seni membangun kepercayaan diri pada bawahan, terutama dalam melaksanakan pendekatan Encourage the Teachers to Participate dan Ensure the Teachers that they Have Capabilities.

\section{DAFTAF PUSTAKA}

Agung Rahmanto. 2019. Menciptakan Label Sekolah Unggul melalui Kegiatan Literasi. Kemdikbud.

Desi Aulia Ulpa. 2018. Pengalaman Terbaik, Pengalaman Lapangan Persekolahan (PLP) di SMA Negeri 11 Muaro Jambi. https://www.academia.edu/37457896/Laporan_Best Practice_Desi_Aulia

Ditjen GTK Kemdikbud. 2018. Penulisan Laporan Best Praktice. Jakarta: Ditjen GTK Kemdikbud.

Karwati, W dan Prawiyogi, A. 2019. Guru dan Membelajarkan Guru. Karawang FBIS Publishing.

Ngalim Purwanto. 1985. Ilmu Pendidikan Teoritis dan Praktis. Bandung: Remadja Karya.

Surjono, H.D. 2018. Best Practice Pembelajaran Daring di UNY. Makalah disajikan dalam Seminar Sosialisasi Pembelajaran Daring. Yogyakarta: Universitas Negeri Yogyakarta

Triatna, Cepi (2015). Membangun Komunitas Belajar Profesional untuk Meningkatkan Mutu Pendidikan di Sekolah. http://ejournal.upiedu/index.php/JPSPs/article/view/ 5918

Widiasworo, Erwin. 2018. Mencetak Generasi Multitalenta. Jakarta: PT Elex Media Komputindo

Yuliani, M., Simarmata, J., Susanti, S. S., Mahawati, E., Sudra, R. I., Dwiyanto, H., ... \& Yuniwati, I. (2020). Pembelajaran daring untuk pendidikan: Teori dan penerapan. Yayasan Kita Menulis. 